by Philip H. Heckel ${ }^{1}$, Aleksandr S. Alekseev ${ }^{2}$, James E. Barrick ${ }^{3}$, Darwin R. Boardman ${ }^{4}$, Natalya V. Goreva ${ }^{5}$, Tatiana N. Isakova ${ }^{6}$, Tamara I. Nemyrovska ${ }^{7}$, Katsumi Ueno ${ }^{8}$, Elisa Villa ${ }^{9}$ and David M. Work ${ }^{10}$

\title{
Choice of conodont Idiognathodus simulator (sensu stricto) as the event marker for the base of the global Gzhelian Stage (Upper Pennsylvanian Series, Carboniferous System)
}

\author{
1 Department of Geoscience, University of Iowa, Iowa City, Iowa 52242, USA. Email: philip-heckel@uiowa.edu \\ 2 Department of Paleontology, Geology Faculty, Moscow State University, 119992 Moscow, Russia. Email: aaleks@geol.msu.ru \\ 3 Department of Geosciences, Texas Tech University, Lubbock, Texas 79409, USA. Email: jim.barrick@ttu.edu \\ 4 School of Geology, Oklahoma State University, Stillwater, Oklahoma 74078, USA. Email: darwin.boardman@okstate.edu \\ 5 Geological Institute, Russian Academy of Sciences, Pyzhevsky per. 7, 110017 Moscow, Russia. Email: goreva@ginras.ru \\ 6 Geological Institute, Russian Academy of Sciences, Pyzhevsky per. 7, 110017 Moscow, Russia. Email: isakova@ginras.ru \\ 7 Institute of Geological Sciences, National Academy of Sciences of Ukraine, O. Gonchar Str. 55b, 01054 Kiev, Ukraine. \\ Email:tnemyrov@i.com.ua \\ 8 Department of Earth System Science, Faculty of Science, Fukuoka University, Fukuoka 814-0180, Japan. Email: katsumi@fukuoka-u.ac.jp \\ 9 Department of Geology, University of Oviedo, Arias de Velasco s/n, 33005 Oviedo, Spain. Email: evilla@geol.uniovi.es \\ 10 Maine State Museum, 83 State House Station, Augusta, Maine 04333, USA. Email: david.work@maine.gov
}

We propose that the level at which the conodont species Idiognathodus simulator (Ellison 1941) (sensu stricto) first appears be selected to mark the base of the Gzhelian Stage, because we believe that this is the optimal level by which this boundary can be correlated. This taxon has a short range and a wide distribution, as shown by correlation of glacial-eustatic cyclothems across the Kasimovian-Gzhelian boundary interval among Midcontinent North America and the Moscow and Donets basins of eastern Europe, based on scale of the cyclothems along with several aspects of biostratigraphy. Outside of these areas, I. simulator (sensu stricto) is known also from other parts of the U.S., and is reported from the southern Urals and south-central China in its expected position between other widespread taxa. Its first appearance is consistent with the current ammonoid placement of the boundary (first appearance of Shumardites cuyleri), and it is also compatible with certain aspects of the distribution of Eurasian fusulinid faunas (e.g., lectotype of Rauserites rossicus).

\section{Introduction}

The Gzhelian Stage is the latest stage of the Pennsylvanian Subsystem and the Carboniferous System. The stage names originating in Russia are now used for the global stages of the Pennsylvanian because most aspects of their fusulinid faunas are similar enough at the generic level that these stages have been readily recognized across much of Eurasia, in contrast to the strongly provincial North American fusulinid faunas. However, on account of this general provinciality of the fusulinid faunas, conodonts are being utilized to mark the events that will be used to define the global stages within the Pennsylvanian, because some of their species are more widespread globally than those of the fusulinids. One such conodont is Idiognathodus simulator (Ellison 1941) (sensu stricto), which was named from Midcontinent North America, and is reported from the Moscow Basin of the Russian Platform (Barskov and Alekseev, 1975; Barskov et al., 1980), the Donets Basin of Ukraine, the southern Ural Mountains of Russia (Chernykh et al., 2006a, b; see also Heckel et al., 2005, 2007) at or near the classic base of the Gzhelian Stage, and in Guizhou Province in south-central China (Wang and Qi, 2002, 2003).

\section{Evolution of the base of the Gzhelian Stage}

The Gzhelian Stage was named by Nikitin (1890) from the village of Gzhel $\sim 60 \mathrm{~km}$ east of Moscow, where it consists of an alternating succession of carbonates, shales, and sandstones. Its base was first defined by brachiopods, then variously recognized by different workers at the first appearance of the fusulinids Rauserites stuckenbergi (Rauser-Chernousova 1938) and/or R. rossicus (Schellwien 1908) (see Ivanova and Rozovskaya, 1967). Later, Barskov and Alekseev (1975) and Barskov et al. (1980) proposed the conodont Idiognathodus simulator, which occurs with $R$. rossicus at Gzhel, to mark the base of the Gzhelian in the Moscow Basin, and more recently it has been used for this purpose in the southern Urals (see references in Chernykh et al., 2006a, b). Most recently, I. simulator has received close attention as the potential event level for the base of the global Gzhelian Stage (Villa and Task Group, 2005; Boardman et al., 2006), both because of its nearly pantropical distribution and because it appears at a level that is consistent with the ammonoid boundary (Bogoslovskaya et al., 1999; Boardman and Work, 2004). 


\section{Characteristics of $I$. simulator (sensu stricto)}

Although originally named as a member of the troughed form genus Streptognathodus by Ellison (1941) and still regarded as such by some workers (e.g., Chernykh, 2005), this species is now regarded by many workers as a grooved descendent of similarly finely ridged species of Idiognathodus that dominate the deeper-water parts of middle and late Missourian (Kasimovian) cyclothems rather than of type Streptognathodus from the same strata (Barrick et al., 2004). The taxonomy of a lineage believed to lead to I. simulator (s.s.) in the southern Urals has recently been published by Chernykh (2005) and Chernykh et al. (2006a, b), who suggest an evolutionary succession at the Usolka section, from I. praenuntius (Chernykh 2005) in bed 4-1 through I. simulator in bed 4-2 to I. auritus (Chernykh 2005) in bed 5, in which I. praenuntius is considered its ancestor. Although the new taxa are defined only by dextral platform elements, Chernykh et al. (2006b) illustrated sinistral elements of I. simulator (s.s.).

Recent study in Midcontinent North America (Barrick, Heckel, and Boardman, 2008) shows that I. simulator (s.s.) is characterized by a distinctly asymmetrical pair of sinistral and dextral Pa elements (Figure 1). The holotype, from the Heebner Shale of the Oread cyclothem (Figure 2), is the more distinctive sinistral element (Figure 1 , specimen 5 ). This element is more strongly curved inward (caudally) such that the transverse ridges are at an oblique angle to the line of the blade, with a strongly eccentric groove close to the inner [caudal] margin. The adcarinal ridges are short and flare outward away from the carina and blade in the anterior (ventral) direction. The dextral element (Figure 1, specimen 6) is straighter with a less well developed eccentric groove, but the adcarinal ridges are similarly short and flaring outward away from the blade. The probable ancestor to $I$. simulator (s.s.) was termed $I$. aff. simulator by Barrick et al. (2004), and is now named I. eudoraensis by Barrick,

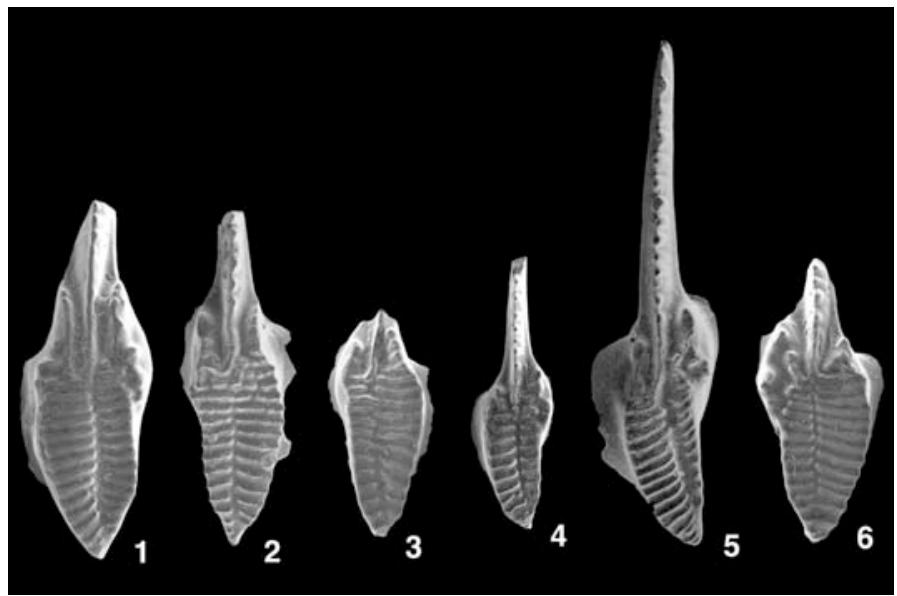

Figure 1 Photographs (25X) of Pa elements of Idiognathodus simulator (Ellison 1941) (sensu stricto) and related forms from older units in Midcontinent North America (see Figure 2 for stratigraphic position).

1. Idiognathodus eudoraensis [sinistral, holotype of new species], Eudora Shale of Stanton cyclothem, Oklahoma.

2. Idiognathodus eudoraensis [dextral], Eudora Shale of Stanton cyclothem, Kansas.

3. Idiognathodus eudoraensis [dextral, probably transitional to Idiognathodus simulator], Gretna Shale of South Bend cyclothem, Kansas.

4. Idiognathodus eudoraensis [sinistral, transitional to Idiognathodus simulator], Little Pawnee Shale of Cass cyclothem, Kansas.

5. Idiognathodus simulator [sinistral, holotype], Heebner Shale of Oread cyclothem, Kansas.

6. Idiognathodus simulator [dextral], Heebner Shale of Oread cyclothem, Nebraska.
Heckel and Boardman (2008). It has a less asymmetrical pair of $\mathrm{Pa}$ elements in which the sinistral element is much less curved inward (caudally), and both elements have longer adcarinal ridges that run parallel to the blade rather than flare outward (Figure 1, specimens 1, 2). I. eudoraensis dominates the Eudora Shale of the second major cyclothem [Stanton] below the Oread cyclothem, which contains the holotype and first appearance of I. simulator. Rare specimens that appear transitional from I. eudoraensis to I. simulator occur in the Gretna Shale (Figure 1, specimen 3: dextral only) of the South Bend intermediate cyclothem and the Little Pawnee Shale (Figure 1, specimen 4) of the major Cass cyclothem between the Stanton and Oread cyclothems (Figure 2). Although Chernykh et al. (2006b) stated that I. aff. simulator (now I. eudoraensis) most probably belongs to $I$. praenuntius, this cannot be certain until the more distinctive sinistral element is studied. It is possible that I. praenuntius is a transitional species distinct from both North American species, considering that I. eudoraensis first appears in the Stanton cyclothem, 4 major to intermediate cyclothems and about $100 \mathrm{~m}$ below the first appearance of I. simulator in the Midcontinent, whereas I. praenuntius first appears only $20 \mathrm{~cm}$ below the first appearance of I. simulator at Usolka in the southern Urals (Chernykh et al., 2006b).

\section{Value of $I$. simulator for global correlation}

Across central North America from Texas through the Midcontinent to Illinois, I. simulator (s.s.) appears within a consistent homotaxial succession of conodont species above a likely ancestor I. eudoraensis (Boardman et al., 2006). Accompanying I. eudoraensis in the Stanton (Midcontinent), Merriman-Upper Winchell (Texas) and Little Vermilion (Illinois) cyclothems is the first appearance of Streptognathodus firmus Kozitskaya 1978, followed upward by $S$. pawhuskaensis (Harris and Hollingsworth 1933) in the South Bend and Lower Ranger (Texas), then S. zethus Chernykh and Reshetkova 1987 in the Cass (Midcontinent) and Omega-Bonpas (Illinois), (not yet certain in the Colony Creek in Texas), which marks the base of the regional Virgilian Stage (Figure 3). I. simulator (s.s.) appears above S. zethus in the Oread (Midcontinent), Finis (Texas), and Shumway (Illinois) cyclothems and is followed upward by co-occurrence of I. tersus Ellison 1941 and S. ruzhencevi (Kozur 1976) in the Lecompton (Midcontinent), Necessity (Texas), and Bogota (Illinois) cyclothems. The ammonoid succession is strongly consistent with the conodont succession in the Midcontinent and Texas, where the ancestral shumarditid Pseudaktubites stainbrooki (Plummer and Scott 1937) and Vidrioceras conlini Miller and Downs 1950 appear with the first appearance of $S$. zethus in the Cass, and in the Lower Colony Creek at the base of the regional Virgilian Stage (Figure 3). Above this, V. uddeni Böse 1919 appears with I. simulator in both the Oread and Finis, along with the earliest Shumardites (S. cuyleri Plummer and Scott 1937) accompanying it in the Finis (Boardman et al., 1994; Boardman and Work, 2004). The first occurrence of these two ammonoids along with I. simulator in the Finis Shale is a key point for global correlation because the evolving ammonoid zonation initiated by Ruzhencev (e.g., 1965) regarded the appearance of these two genera to characterize the Shumardites-Vidrioceras Genozone, which now corresponds to the base of the Gzhelian Stage (Bogoslovskaya et al., 1999; Boardman and Work, 2004). The appearance of the older ammonoids with S. zethus defines the Pseudaktubites stainbrooki-Vidrioceras conlini Subzone (emended from Boardman and Work, 2004), which lies at the base of the regional Virgilian Stage. In both the Moscow and southern Urals region of Russia, I. simulator occurs above $S$. zethus and below $S$. vitali Chernykh 2002. We recognize that the two cyclothems of lesser scale in the Midcontinent (Amazonia, Toronto) and Texas (Upper Colony Creek, Home Creek) below the Oread-Finis cyclothem (in which I. simulator and its accompanying ammonoids occur) and above the Cass-Lower Colony Creek cyclothem (in which $S$. zethus and its accompanying ammonoids occur) lack the 


\begin{tabular}{|c|c|c|c|c|c|}
\hline $\begin{array}{l}\frac{w}{\tilde{\alpha}} \\
\frac{\tilde{w}}{\omega}\end{array}$ & 岁 & $\begin{array}{c}\text { MIDCONTINENT } \\
\text { NORTH AMERICA } \\
\text { MAJOR CYCLOTHEM } \\
\text { [core shale]; } \\
\text { Intermediate cyclothem }\end{array}$ & $\begin{array}{l}\text { MOSCOW } \\
\text { BASIN } \\
\text { Cyclothems }\end{array}$ & $\begin{array}{c}\text { DONETS } \\
\text { BASIN } \\
\text { Cyclothems }\end{array}$ & $\begin{array}{l}\text { SOUTH } \\
\text { URALS } \\
\text { USOLKA } \\
\text { Beds }\end{array}$ \\
\hline \multirow{14}{*}{ 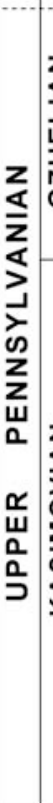 } & \multirow{4}{*}{ 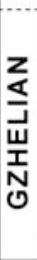 } & $\begin{array}{l}\text { DEER CREEK } \\
\text { [Larsh-Burroak] }\end{array}$ & & $\begin{array}{l}\text { P1 } \\
\text { l. luganicus }\end{array}$ & \\
\hline & & $\begin{array}{l}\text { LECOMPTON } \\
\text { [Queen Hill] }\end{array}$ & $\begin{array}{l}\text { AMEREVO } \\
\text { I. simulator }\end{array}$ & $\begin{array}{l}\text { O7 } \\
\text { I. luganicus }\end{array}$ & $\begin{array}{l}\text { Bed 5-1 } \\
\text { I. auritus otc. }\end{array}$ \\
\hline & & $\begin{array}{l}\text { OREAD [Heobner] } \\
\text { type I. simulator } \\
\text { [holotype is sinistral] }\end{array}$ & $\begin{array}{l}\text { UPPER } \\
\text { RUSAVKINO } \\
\text { l. simulator }\end{array}$ & $\begin{array}{l}\mathrm{O} \\
\text { I. simulator }\end{array}$ & $\begin{array}{l}\text { Bed } 4-2 \\
\text { I. simulator } \\
\text { I. sinistrum } \\
\text { I. auritus }\end{array}$ \\
\hline & & Iproposed & of global & Gzholian & Stagej \\
\hline & \multirow{10}{*}{ 走 } & Toronto & & & \\
\hline & & $\begin{array}{l}\text { CASS [Littlo Pawnee] } \\
\text { I. eudoraensis [transi- } \\
\text { tional to I. simulator] }\end{array}$ & $\begin{array}{l}\text { MIDDLE } \\
\text { RUSAVKINO } \\
\text { I. eudoraensis } \\
\text { [transitional?] }\end{array}$ & $\begin{array}{l}\text { O5 } \\
\text { I. eudoraensis }\end{array}$ & $\begin{array}{l}\text { Bod 4-1 typo } \\
\text { l. praenuntius } \\
\text { [dextral only] }\end{array}$ \\
\hline & & $\begin{array}{l}\text { [base of regional } \\
\text { Virgilian Stage] }\end{array}$ & & & \\
\hline & & latan & Lwr. Rusavkino & & \\
\hline & & $\begin{array}{l}\text { South Bend [Gretna] } \\
\text { l. eudoraensis } \\
\text { [dextral, transitional? } \\
\text { to } 1 . \text { simulator] }\end{array}$ & Basal Rusavkino & & \\
\hline & & $\begin{array}{l}\text { STANTON [Eudora] } \\
\text { type I. eudoraensis } \\
\text { [holotype is sinistral] }\end{array}$ & $\begin{array}{l}\text { TROSHKOVO } \\
\text { I. eudoraensis } \\
\text { I. toretzianus }\end{array}$ & $\begin{array}{l}04 / 6 \\
\text { 1. toretzianus }\end{array}$ & \\
\hline & & Plattsburg [Hickory Ck] & Myasnitskaya & $04 / 5$ & \\
\hline & & Wyandotte [Quindaro] & Sadovaya & $04 / 4$ & \\
\hline & & $\begin{array}{c}\text { IOLA [Muncie Creek] } \\
\text { I. magnificus }\end{array}$ & $\begin{array}{l}\text { Presnya } \\
\text { 1. toretzianus }\end{array}$ & $04 / 3$ & \\
\hline & & $\begin{array}{l}\text { DEWEY [Quivira] } \\
\text { 1. magnificus [type in Tx] }\end{array}$ & MESTSHERINO & $\begin{array}{l}\text { O4/1 type } \\
\text { 1. toretzianus }\end{array}$ & \\
\hline
\end{tabular}

Figure 2 Middle Missourian through early Virgilian major (upper case) and intermediate (lower case) cyclothem succession in Midcontinent North America, and correlative cyclothems elsewhere, showing stratigraphic occurrences (in bold face) of Idiognathodus simulator (s.s.), its probable ancestor, I. eudoraensis, transitional forms, and related species (in bold face). Also shown are units containing its possible precursors, the I. magnificus lineage in North America and I. toretzianus in eastern Europe. See Figure 3 for detail on correlation. Simulator group lineages seem to have non-continuous occurrences, because they are confined to offshore facies, which occur only in major cyclothems and one intermediate cyclothem, all of which are separated from one another by disconformities in Midcontinent, Moscow, and Donets basins. Cyclothems are not recognized in southern Urals at Usolka section, where other species related to I. simulator have been described by Chernykh (2005).

deeper water facies in which these taxa are typically found, but this problem is inherent on shelves in the strongly glacial-eustatically controlled cyclic succession in this part of the Pennsylvanian.

\section{Basis for correlation of cyclothems}

In the revised ICS guidelines for establishing global chronostratigraphic boundaries, Remane et al. (1996) emphasized that correlation of the strata encompassing a boundary interval must precede the definition of the boundary by the marker event of optimal correlation potential selected for establishing a GSSP. The generally acknowledged difficulty in global correlation of Pennsylvanian strata because of geographic provincialism is now being alleviated by recognition of the general glacial-eustatic control over the marine cyclothems separated by terrestrial deposits and exposure surfaces that characterize Pennsylvanian stratigraphy in shelf regions. The Middle to Late Pennsylvanian succession of widespread marine cyclothems recognized in the Midcontinent has been correlated across large parts of the United States (Boardman and Heckel, 1989; Heckel, 1994, 2002; Ritter et al., 2002), using the distinctive succession of conodont faunas within the successive cyclothems (Barrick et al., 2004). Recognizing the global control of glacial eustasy, modern Russian stratigraphers have now identified the exposure surfaces separating cyclothems in the Moscow region and have begun to correlate the cyclothems across the Russian Platform (e.g., Kabanov, 2003; Kabanov and Baranova, 2007). Cyclothems can also be recognized in the Donets Basin of Ukraine and adjacent Russia, where marine carbonates and shale alternate with terrestrial clastics and coal. Recent progress in working out the conodont successions in North America (Barrick et al., 2004) and eastern Europe (Goreva and Alekseev, 2006; Alekseev and Goreva, 2007) has shown that while a fair amount of provincialism exists, there are levels where distinctive taxa are found across most of these regions. Therefore we have established a correlation of the glacial-eustatic cyclothems across the Kasimovian-Gzhelian boundary interval among these regions where they are recognized (Heckel et al., 2007), and compared it with the biostratigraphic succession in the western slope of the southern Urals where the distinctive sinistral element of I. simulator has been illustrated by Chernykh et al. (2006b), but cyclothems are not yet recognized.

To establish the most reasonable correlation, the following assumptions of Heckel et al. (2005, 2007) apply: [1] Because they are glacial-eustatic, the scale of each cyclothem, that is, its relative lateral extent and water depth attained, should be roughly the same globally compared to that of the adjacent cyclothems. This assumes that local differential tectonism acts too slowly (1-2 m.y.) to mask the pattern in the more frequent fluctuations in sea level (20-400 k.y.) that resulted in the particular succession of major, intermediate and minor cyclothems, which is well documented in Midcontinent North America and correlated into Texas (Boardman and Heckel, 1989) and the Illinois and Appalachian basins (Heckel, 1994, 1999, 2002). This should be true for the cratonic Midcontinent and Russian Platform, but may be less so in the Donets Basin where tectonic forces may have affected the strata during deposition in the aulacogen. [2] Major cyclothems with the greatest lateral extent of marine facies and the deepest-water facies on the shelves should be the most readily correlated, both because they contain deeper-water as well as shallow-water fossils, and because they would have allowed the greatest interchange of conspecific organisms across the inundated shelves of the pantropical realm. [3] Conodonts and ammonoids are the primary fossils used to correlate the cyclothems because they were likely largely pelagic, whereas the benthic and more provincial fusulinids are used only secondarily. [4] Major cyclothems are recognized in the Midcontinent by means of their conodont-rich dark phosphatic shale facies that resulted from water deep enough and far enough from shoreline to significantly reduce detrital dilution. Major cyclothems are recognized in the Moscow Basin of the Russian Platform and in the Donets Basin also by means of greatest conodont abundance, which similarly reflects decreased sediment dilution in the deepest-water facies. In the Moscow Basin these facies are often shaly limestones (sometimes with tempestite beds) in contrast to the adjacent purer, shallower-water limestones (Kabanov et al., 2006). In the Donets Basin, these facies are usually in the non-algal limestone beds.

\section{Correlation of cyclothems across Kasimovian-Gzhelian boundary interval}

Using these guidelines, and including the north-central Texas succession for its ammonoid information, the following correlations are made across the Kasimovian-Gzhelian boundary interval (Figure 3): The major North American Midcontinent Oread cyclothem and Texas Finis cyclothem are correlated with the major Upper Rusavkino cyclothem of Russia and Donets Basin Limestone $\mathrm{O}_{6}$, based on the first appearance of the distinctive conodont Idiognathodus simulator (s.s.) in all regions. Correlation of the Oread with the Finis cyclothem is strongly supported by the first appearance of the ammonoid Vidrioceras uddeni in both (Boardman and Work, 2004). Two major cyclothems below this correlated cyclothem, the Midcontinent Stanton and Texas Merriman-Upper Winchell cyclothems 


\begin{tabular}{|c|c|c|c|c|c|}
\hline $\begin{array}{l}\text { N. AM. MIDCONTINENT Cyclothems } \\
\text { [MAJOR (core shale), intermediate, Minor] }\end{array}$ & $\begin{array}{l}\text { NORTH-CENTRAL TEXAS } \\
\text { [same scaling as Midcontinent] }\end{array}$ & $\begin{array}{l}\text { MOSCOW BASIN } \\
\text { [MAJOR, lesser cycle] }\end{array}$ & $\begin{array}{l}\text { DONETS BASIN, Kalinovo } \\
\text { [MAJOR, lesser cycle] }\end{array}$ & $\begin{array}{l}\text { SOUTHERN URALS } \\
\text { Dalniy Tyulkas-2; Usolka }\end{array}$ & $\begin{array}{l}\text { SOUTH URALS } \\
\text { Nikolsky }\end{array}$ \\
\hline $\begin{array}{l}\text { LECOMPTON (Queen Hill): L. tersus, } \\
\text { S. pawhuskaensis, S. ruzhencevi, S. vitali } \\
\text { nondiagnostic ammonoids }\end{array}$ & $\begin{array}{l}\text { NECESSITY: I. tersus, S. vitali, } \\
\text { S. pawhuskaensis, S. ruzhencevi } \\
\text { amm. Shumardites simondsi }\end{array}$ & $\begin{array}{l}\text { AMEREVO: I. simulator, } \\
\text { S. ruzhencevi, S. vitali } \\
\text { fus. Rauserites stuckenbergi }\end{array}$ & $\begin{array}{l}\text { O7 [?]: type S./. luganicus, } \\
\text { I. tersus, I. cf. simulator } \\
\text { fus. R. rossicus [06/1 here?] }\end{array}$ & $\begin{array}{l}\text { Usolka bed } 5: S / \text {. auritus } \\
\text { DT-2 bed } 47 \text { : } \\
\text { fus Rauserites stuckenbergi }\end{array}$ & $\begin{array}{l}\text { Bed 12: S. vitali [or } \\
\text { younger?] } \\
\text { Bed 10: } \\
\text { fus. R. stuckenbergi }\end{array}$ \\
\hline Spring Branch: I. tersus, S pawhuskaensis & Bunger: S. pawhuskaensis & [not identified] & $\begin{array}{l}\text { O6/1?: S. firmus, I. toretzianus } \\
\text { fus. Jigulites makbalensis }\end{array}$ & & \\
\hline Clay Creek: I. tersus, S pawhuskaensis & North Leon: [not known] & [not identified] & [or $06 / 1$ here?] & & \\
\hline $\begin{array}{l}\text { OREAD (Heebner) } \\
\text { first } I \text {. simulator [type], } \\
\text { I. tersus [above I. simulator]. } \\
\text { S. firmus, S. pawhuskaensis } \\
\text { amm. Vidrioceras uddeni }\end{array}$ & \begin{tabular}{|l|} 
FINIS: \\
first I. simulator, \\
I. tersus, S. firmus, \\
S. pawhuskaensis \\
first global Shumardites (S. cuyleri), \\
Vidrioceras uddeni, V. conlini
\end{tabular} & $\begin{array}{l}\text { UPPER RUSAVKINO: } \\
\text { first } I \text {. simulator, } \\
\text { S. firmus, S. pawhuskaensis, } \\
\text { I. tersus, Gondolella } \\
\text { fus. lectotype Rauser. rossicus } \\
\end{array}$ & $\begin{array}{l}\text { O6: } \\
\text { first I. simulator, } \\
\text { S. fimus, I. toretzianus } \\
\text { fus. Triticites sp. }\end{array}$ & $\begin{array}{l}\text { Usolka bed } 4.2 \text { : } \\
\text { first } I \text {. simulator, } \\
\text { type S. sinistrum, } S \text {. auritus } \\
\text { DT-2 bd } 46: \text { I. simulator } \\
\text { [traditional base of }\end{array}$ & $\begin{array}{l}\text { I. simulator [reported] } \\
\text { fus. Jigulites } \\
\text { makbalensis } \\
\text { Gzhelian in Urals] }\end{array}$ \\
\hline [PROPOSED & OF $\quad$ GLOBAL & GZHELIAN & STAGE] & & \\
\hline $\begin{array}{l}\text { Toronto: S pawhuskaensis } \\
\text { Amazonia: S. pawhuskaensis }\end{array}$ & $\begin{array}{l}\text { Home Creek: S. pawhuskaensis } \\
\text { Upr. Colony Ck: [no conodonts] }\end{array}$ & $\begin{array}{l}\text { [not identified] } \\
\text { [not identified] }\end{array}$ & $\begin{array}{l}\text { [not identified] } \\
\text { [not identified] }\end{array}$ & & \\
\hline $\begin{array}{l}\text { CASS (Little Pawnee): S. pawhuskaensis, } \\
\text { S. zethus, S. firmus, rare } I \text {. eudoraensis } \\
\text { transitional to I. simulator }\end{array}$ & $\begin{array}{l}\text { LOWER COLONY CREEK: } \\
\text { S. pawhuskaensis, S. zethus? }\end{array}$ & $\begin{array}{l}\text { MIDDLE RUSAVKINO: } \\
\text { S. zethus, I. eudoraensis, } \\
\text { S. pawhuskaensis, S, firmus }\end{array}$ & $\begin{array}{l}\text { O5: type S. firmus dominant, } \\
\text { S. zethus, I. eudoraensis, } \\
\text { S. pawhuskaensis }\end{array}$ & $\begin{array}{l}\text { Usolka bed 4-1: type S./. } \\
\text { praenuntius [dextral only] } \\
\text { type S. zethus }\end{array}$ & \\
\hline $\begin{array}{l}\text { ammonoids Pseudaktubites stainbrooki, } \\
\text { Vidrioceras conlini }\end{array}$ & $\begin{array}{l}\text { amm. Pseudaktubites stainbrooki, } \\
\text { Vidrioceras conlini }\end{array}$ & fus. rare, poorly known & $\begin{array}{l}\text { fus. primitive Rauserites rossicus, } \\
\text { Jigulites makbalensis }\end{array}$ & $\begin{array}{l}\mathrm{DT}-2 \text { bed } 42: \mathrm{S} \\
\text { l. eudoraensis }\end{array}$ & $\begin{array}{l}\text { fus. } R \text {. variabilis, } \\
R \text {. quasiarcticus }\end{array}$ \\
\hline [base of & Virgilian & [previous base of Gzhelian] & [inferred base of Gzhelian] & & \\
\hline Westphalia: S. pawhuskaensis & Upmost Ranger. S pawhuskaensis & [not identified] & [not identified] & & \\
\hline $\begin{array}{l}\text { latan: } \\
\text { S. pawhuskaensis, S. firmus }\end{array}$ & $\begin{array}{l}\text { Upper Ranger: } \\
\text { S. pawhuskaensis. S. firmus }\end{array}$ & $\begin{array}{l}\text { Lower Rusavkino: } \\
\text { S. firmus, I. toretzianus }\end{array}$ & [not identified] & & \\
\hline $\begin{array}{l}\text { South Bend (Gretna): S firmus, } \\
\text { first } S \text {. pawhuskaensis, rare } I \text {, eudoraensis }\end{array}$ & $\begin{array}{l}\text { Lower Ranger. S. firmus, } \\
\text { S. pawhuskaensis }\end{array}$ & $\begin{array}{l}\text { Basal Rusavkino: } \\
\text { 1. aff. toretzianus }\end{array}$ & [not identified] & & $\begin{array}{l}\text { Bed 5: S. firmus, } \\
\text { S. pawhuskaensis }\end{array}$ \\
\hline $\begin{array}{l}\text { STANTON (Eudora): S. firmus in top; } \\
\text { type } I \text {. eudoraensis, S. gracilis group in base } \\
\text { amm. Pseudaktubites newelli }\end{array}$ & $\begin{array}{l}\text { MERRIMAN-UPR. WINCHELL: } \\
\text { L. eudoraensis, S. firmus } \\
\text { juvenile ammonoids only }\end{array}$ & $\begin{array}{l}\text { TROSHKOVO: } \\
\text { L. eudoraensis, I. toretzianus } \\
\text { fus. rare } R \text {. quasiarcticus }\end{array}$ & $\begin{array}{l}\text { O4/6: S. firmus dominant, } \\
\text { S. isakovae, I. toretzianus, } \\
\text { I. bachmuticus }\end{array}$ & & \\
\hline Plattsburg (Hickory Creek): S. gracilis group & Mid-Winchell: S. gracilis group & Myasnitskaya: type S, isakovae & O4/5: [poorly known] & & \\
\hline Wyandotte (Quindaro): S. gracilis group & Lower Winchell: rare conodonts & Sadovaya: flat plus troughed & 04/4: [poorly known] & & \\
\hline $\begin{array}{l}\text { IOLA (Muncie Creek): S. gracilis group, } \\
\text { I. 'postmagnificus', other flat forms }\end{array}$ & $\begin{array}{l}\text { LOWER WOLF MOUNTAIN: } \\
\text { type S. elegantulus, S. excelsus }\end{array}$ & $\begin{array}{l}\text { Presnya: S. isakovae, } \\
\text { 1. toretzianus }\end{array}$ & $\begin{array}{l}\text { O4/3: S. firmus, S. isakovae, } \\
\text { [type S. kalitvensis, S. excelsus] }\end{array}$ & & \\
\hline Mid-Chanute: [no conodonts] & [not identified] & [not identified] & O $4 / 2$ : no conodonts & & \\
\hline $\begin{array}{l}\text { DEWEY (Quivira): S. gracilis group, } \\
\text { l. magnificus, other flat forms, } \\
\text { Gondolella }\end{array}$ & $\begin{array}{l}\text { MID-POSIDEON S. gracilis group, } \\
\text { type L. magnificus, S. gracilis, } \\
\text { Gondolella }\end{array}$ & $\begin{array}{l}\text { MESTSHERINO: } \\
\text { type l. mestsherensis, } \\
S \text {. isakovae, Gondolella }\end{array}$ & $\begin{array}{l}\text { O4/1: S. firmus, S. isakovae, } \\
\text { [type } I . \text { bachmuticus], } \\
\text { [type } I \text {. toretzianus] }\end{array}$ & & \\
\hline Drum-Westerville: S. gracilis group & [not identified] & [not identified] & [not identified] & & \\
\hline Cherryvale (Wea): S. gracilis group & Lower Posideon: S. gracilis group & $\begin{array}{l}\text { Perkhurovo: flat forms, } \\
\text { S. neverovensis }\end{array}$ & $\begin{array}{l}\text { O4: mostly troughed forms } \\
\text { fus. Rausentes aff. rossicus, etc. }\end{array}$ & & \\
\hline $\begin{array}{l}\text { Hogshooter. some flat forms, } \\
\text { some transitional to } S \text {. gracilis group }\end{array}$ & $\begin{array}{l}\text { Lowermost Posideon: } \\
\text { [poorly known] }\end{array}$ & [not identified] & $\begin{array}{l}\text { O3: flat plus troughed forms } \\
\text { fus. Quasifusulina, Quas'oides }\end{array}$ & & \\
\hline $\begin{array}{l}\text { DENNIS (Stark): many forms, including } \\
\text { type S. confragus } \\
\text { fus. Triticites [not most primitive] }\end{array}$ & $\begin{array}{l}\text { PALO PINTO: many forms, incl. } \\
\text { S. confragus } \\
\text { fus. Triticites cf. ohioensis }\end{array}$ & $\begin{array}{l}\text { UPPER NEVEROVO: many, } \\
\text { incl. S. cf. cancellosus } \\
\text { fus. Montiparus subcrassulus }\end{array}$ & $\begin{array}{l}\text { O2: mostly flat forms, but incl. } \\
\text { S. cf. confragus } \\
\text { fus. Triticites, adv. Montiparus }\end{array}$ & & $\begin{array}{l}\begin{array}{l}\text { Bed } 2 \text { fus. Montiparus } \\
\text { subcrassulus }\end{array} \\
\end{array}$ \\
\hline
\end{tabular}

Figure 3 Correlation of cyclothems across Kasimovian-Gzhelian Stage boundary in North America and Eurasia, based on authors' information and the following published sources: Midcontinent and Texas (Boardman and Heckel, 1989; Boardman et al., 1994; Boardman and Work, 2004; Heckel, 2002), Moscow Basin (Anonymous, 1998; Alekseev, et al., 2004; Alekseev and Goreva, 2007), Donets Basin (Aizenverg et al., 1975; Davydov, 1992; Nemyrovska and Kozitska, 1999), with reports of occurrences from sections other than Kalinovo shown in brackets because correlations of numbered limestones among sections are not necessarily accurate; Southern Urals (Davydov, 1986; Alekseev et al., 2002; Chernykh et al., 2006a, b; V.I. Davydov, personal communication, 2005). Horizontal lines separating rows in four left-hand columns represent disconformities separating cyclothems, but are extended as dashed lines into two right-hand columns only as guidelines for correlation of beds in these presumably more continuously deposited successions. (Expanded and updated from Heckel et al., 2007).

are correlated with the Russian Troshkovo cyclothem, based on the first appearance of I. eudoraensis, the probable ancestor of I. simulator (s.s.). The major cyclothem between these two correlated cyclothems, the Midcontinent Cass cyclothem is correlated with the Lower Colony Creek cyclothem of Texas by the appearance of the ammonoids Vidrioceras conlini and Pseudaktubites stainbrooki in both, and with both the Middle Rusavkino cyclothem of Russia and Donets Limestone $\mathrm{O}_{5}$ by the first occurrence of the conodont Streptognathodus zethus in both. The next major cyclothem above the Oread-Upper-Rusavkino- $\mathrm{O}_{6}$ cyclothem, the Midcontinent Lecompton and Texas Necessity cyclothems are correlated by the first appearance of $S$. ruzhencevi and $S$. vitali, along with the presence of I. tersus, and these two cyclothems are correlated with the Amerevo cyclothem of Russia by the appearance of S. ruzhencevi and S. vitali.

The upward succession of 5 intermediate and major cyclothems below the Stanton-Troshkovo cyclothem (Figure 3) and above the Dennis-Upper Neverovo- $\mathrm{O}_{2}$ cyclothem in North America (Cherryvale, Dewey, Iola, Wyandotte, Plattsburg) lines up well by position with the five cyclothems in Russia (Perkhurovo, Mestsherino, Presnya, Sadovaya, Myasnitskaya, respectively), with only the third cyclothem upward (minor Presnya) not at the same relative scale as its positional equivalent (Iola) in North America (see also Heckel et al., 2007). The Donets conodont succession below I. simulator in Limestone $\mathrm{O}_{6}$ is less well known than it is in Russia, but so far appears to be dominated by S. firmus and I. toretzianus Kozitskaya 1978, both long-ranging forms that were named from this area. S. firmus appears abruptly in the Midcontinent in the upper Eudora Shale (Stanton cyclothem) by migration, and extends upward to the Oread. The Donets succession contains $S$. zethus and I. eudoraensis recently discovered in Limestone $\mathrm{O}_{5}$, which allows correlation with the Cass and Middle Rusavkino, but the Donets units below this are correlated mainly by position and scale. Below $\mathrm{O}_{5}$, the downward succession of three major Donets cycles $\left(\mathrm{O}_{4}{ }^{6}, \mathrm{O}_{4}{ }^{3}\right.$, and $\left.\mathrm{O}_{4}{ }^{1}\right)$ line up well with the three major cyclothems in North America (Stanton, Iola, and Dewey, respectively), providing a more reasonable correlation of these higher Donets cycles than shown by Heckel et al. (2005), since the more recent discovery of the first I. simulator (s.s.) in Donets cycle $\mathrm{O}_{6}$, rather than in $\mathrm{O}_{7}$ as previously thought. Thus, even if the correlation of the Oread-Upper Rusavkino-O 6 cyclothem were not based on the first appearance of I. simulator, the overall correlation framework of nearly all the major middle and late Kasimovian and early Gzhelian cyclothems based on cyclothem scale and first conodont and ammonoid appearances still provides the most reasonable framework possible (Figure 3). Above $\mathrm{O}_{6}$, correlation of the Donets succession is less certain because $\mathrm{O}_{6}{ }^{1}$ contains a continuation of the older $S$. firmus $-I$. toretzianus fauna, while $\mathrm{O}_{7}$ contains the first appearance of $I$. tersus, which first appears in the Midcontinent in the Oread and dominates the next three intermediate 
to major cyclothems upward to the Lecompton (and the Necessity in Texas), above which it is absent. Therefore, $\mathrm{O}_{7}$ is provisionally correlated with the Lecompton-Necessity cyclothem (and by extension with the Amerevo of Russia) because of the presence of I. tersus. This places $\mathrm{O}_{6}{ }^{1}$ equivalent to either of the two intermediate cyclothems between the Oread and Lecompton in the Midcontinent (Clay Creek or Spring Branch), but until Gzhelian conodont faunas of the Donets Basin are better known, we cannot rule out the possibility that $\mathrm{O}_{6}{ }^{1}$ might correlate with the Lecompton-NecessityAmerevo cyclothem, while $\mathrm{O}_{7}$ is younger. $\mathrm{O}_{7}$ also contains the holotype of S. luganicus Kozitskaya 1978 and other simulator-like forms that we term I. cf. simulator, which resemble similar forms in strata younger than bed 4-2 at Usolka in the southern Urals.

Among fusulinids, Rauserites rossicus first appears with I. simulator in the Upper Rusavkino at the Gzhel section near Moscow (Figure 3), source of the recently designated lectotype (Isakova and Ueno, 2007). Current work reports $R$. rossicus similar to the Gzhel lectotype from Donets Limestone $\mathrm{O}_{7}$, which by conodont data is younger than the Upper Rusavkino, and more primitive $R$. rossicus from Limestone $\mathrm{O}_{5}$, which is older than the Upper Rusavkino, although all 3 morphotypes are close enough to be considered subspecies of the same species. Recent choice of the lectotype from Gzhel facilitates the usage of $R$. rossicus to identify the base of the Gzhelian in facies where I. simulator is not found. This has been current practice in many areas, such as Arctic Russia where $R$. rossicus appears at or above the base of the Gzhelian (see Remizova, 2006). Among other fusulinids, Jigulites makbalensis Davydov 1986, which is considered Gzhelian, is reported to appear in Donets Lime-

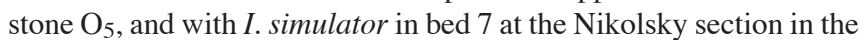
southern Urals (see below). Thus some fusulinid species, as currently designated, apparently are not sufficient for accurate cyclothem-level correlation, although their appearance may indicate a position close to the level of I. simulator. Therefore, we rely on the conodonts and ammonoids along with cycle scale as the primary basis for the cyclothem correlation shown in Figure 3.

Correlation of the successions in which cyclothems are not identified is based mainly on the succession of conodonts, again using fusulinids where they appear helpful. In the Dalniy Tyulkas-2 section of the southern Urals, the upward appearances of S. zethus and I. eudoraensis in bed 42, of I. simulator in bed 46, and of the fusulinid Rauserites stuckenbergi in bed 47, indicate correlation of this part of the succession, respectively, with the Cass-Middle Rusavkino- $\mathrm{O}_{5}$ cyclothem, the Oread-Upper Rusavkino-- 6 cyclothem, and the Lecompton-Amerevo cyclothem (Figure 3). In the nearby Usolka section of siliceous carbonates, the presence of type $S$. zethus in bed 4-1 (along with type S. praenuntius, another possible ancestor of I. simulator), and I. simulator (s.s.) in bed 4-2, suggest correlation of this part of the section with the Cass-Middle Rusavkino- $\mathrm{O}_{5}$ and Oread-Upper Rusavkino- $\mathrm{O}_{6}$ cyclothems, respectively. In the detrital siliciclastic Nikolsky section not far away, the presence of both S. firmus and S. pawhuskaensis in bed 5, the appearance of I. simulator in bed 7, the appearance of $R$. stuckenbergi in bed 10 and the appearance of $S$. vitali in bed 12, suggest correlation of this part of the succession, respectively, with the South Bend cyclothem of the Midcontinent, the Oread-Upper Rusavkino- $\mathrm{O}_{6}$ cyclothem, and the Lecompton-Amerevo cyclothem, although bed 12 could be younger.

In south-central China, Idiognathodus simulator has been reported (as Streptognathodus simulator) from a narrow stratigraphic interval in the Nashui section near Luodian in Guizhou Province (Wang and Qi, 2002, 2003). There it defines the S. simulator Zone, which lies between two locally named zones, but is appropriately positioned between two zones that are based on middle Missourian/Kasimovian species below and late Gzhelian species of Streptognathodus above.

\section{Conclusions}

The relative ease of correlation of the Oread-Upper Rusavkino--O 6 cyclothem by means of the first appearance of I. simulator [s.s.] in all regions above strata that contain the first appearance of $S$. zethus (the Cass-Middle Rusavkino- $\mathrm{O}_{5}$ cyclothem) and I. eudoraensis (the Stanton-Troshkovo cyclothem) indicates that this appearance would provide a good marker event for defining the base of the Gzhelian Stage (Figures 2, 3). The appearance with I. simulator in this cyclothem in Texas of the earliest species of Shumardites, $S$. cuyleri, serves to keep the base of the Gzhelian at its proper position in terms of the recently emended ammonoid zonations of Boardman et al. (1994) and Bogoslovskaya et al. (1999). The appearance of the lectotype of the fusulinid Rauserites rossicus with I. simulator in the Moscow region and forms similar to $R$. rossicus above I. simulator in the Donets Basin, indicate that morphotypes of this fusulinid should aid in identifying this boundary in Eurasia.

Ironically, the widespread exposure surfaces that help to expedite correlation will make the selection of GSSPs (which require continuous sedimentation) difficult in the shelf regions where the cyclothems are well defined. However, the correlation of sections in which cyclothems are not recognized into this cyclothem framework should allow the possibility of selecting a GSSP in a section of continuous sedimentation that can be correlated globally (at least in the pantropical belt), if several conditions are met (Heckel et al., 2007): [1] Cyclothems are not recognized because the section was deposited at greater water depth below sea-level lowstand; [2] the section contains a complete succession of fossils that occur also in the more shelfward regions where the correlation framework is recognized; and [3] the section is on a slope gentle enough that the continuity is not interrupted by debris flows that may have eliminated a significant amount of strata or mixed biotas of different ages. The Usolka section near Krasnousolsk in the southern Urals may provide the requisite characteristics for defining a GSSP for the KasimovianGzhelian boundary at this level (Chernykh et al., 2006a, b), as it appears to be a slope deposit, but it must undergo further thorough lithic and biostratigraphic study to confirm its potential as a candidate. In addition, the Nashui section near Luodian in south-central China also is a slope deposit (Wang and Qi, 2003), and it also will undergo further detailed lithic and biostratigraphic study for its consideration as a candidate for the GSSP.

\section{Acknowledgments}

Among the authors, Heckel coordinated and compiled information from all authors and established the correlations; Barrick and Boardman provided conodont information for the Midcontinent; Work and Boardman provided ammonoid information for the Midcontinent and perspective on ammonoids reported elsewhere; Alekseev and Goreva provided information for correlations in the Moscow region and Dalniy Tyulkas in the Urals; Isakova provided information on critical fusulinids in eastern Europe; Nemyrovska provided conodont and cycle-scale information for correlations in the Donets Basin; Ueno provided fusulinid information for the Donets Basin; Villa chaired the task group that is dealing with this stage boundary, and provided perspective on fusulinid information. We thank all other members of the SCCS Task Group on the Kasimovian-Gzhelian Boundary for providing information, thoughtful correspondence and discussions at meetings, particularly V.I. Davydov and V.V. Chernykh who provided information on fusulinids and conodonts in the Usolka and Nikolsky sections in the southern Urals, and along with H.C. Forke, made helpful comments on the manuscript; other task group members include A. V. Dzhenchuraeva, B. Fohrer, O.L. Kossovaya, L.L. Lambert, C.A. Mendez, M.L. Martinez Chacon, L.C. Sanchez de Posada, S.T. Remizova, E. Sammankassou, and G.P. Wahlman. 


\section{References}

Aizenverg, D. E., and 19 others, 1975, Field excursion guidebook for the Donets Basin: Publishing Office <Nauka $>$, Moscow, 360 p.

Alekseev, A.S., and Goreva, N.V., 2007, Conodont zonation for the type Kasimovian and Gzhelian stages in the Moscow Basin, Russia, in Wong, Th. E., ed., Proceedings of the XVth International Congress on Carboniferous and Permian Stratigraphy. Utrecht, the Netherlands, August 2003. Royal Netherlands Academy of Arts and Sciences, p. 229-242.

Alekseev, A.S., Goreva, N.V., Isakova, T.N., and Makhlina, M.Kh., 2004, Biostratigraphy of the Carboniferous in the Moscow Syneclise, Russia: Newsletter on Carboniferous Stratigraphy, v. 22, p. 28-35.

Alekseev, A.S., Goreva, N.V., Kulagina, E.I., Kossovaya, O.L., Isakova, T.N., and Reimers, A.N., 2002, Upper Carboniferous of South Urals (Bashkiria, Russia), Guidebook for field trip of working group to establish GSSP in upper part of Carboniferous System August 10-18, 2002, Moscow and Ufa: Moscow State University; Geological Institute of Russian Academy of Sciences; Institute of Geology, Ufa Research Center of Russian Academy of Sciences. 56 p.

Anonymous [A.S. Alekseev and colleagues], 1998, Type and reference sections of Serpukhovian, Moscovian, Kasimovian and Gzhelian stages in Moscow Basin, Field-Trip Guidebook 7-13 August, 1998: Commission on Carboniferous System of Russia on central and southern Russian Platform. Geology faculty of Moscow State University. Paleontological and Geological Institutes of the Russian Academy of Sciences.(unnumbered pages).

Barrick, J.E., Heckel, P.H., and Boardman, D.R., 2008, Revision of the conodont Idiognathodus simulator (Ellison 1941), the marker species for the base of the Late Pennsylvanian global Gzhelian Stage: Micropaleontology, v. 54, no. 2, p. 125-137.

Barrick, J.E., Lambert, L.L., Heckel, P.H., and Boardman, D.R., 2004, Pennsylvanian conodont zonation for Midcontinent North America: Revista Espanola de Micropaleontologia, v. 36, p. 231-250.

Barskov, I.S., and Alekseev, A.S., 1975, Conodonts of the Middle and Upper Carboniferous of the Moscow Basin: Isvestiya Akademii Nauk, Seriya Geologicheskaya, no. 6, p. 84-99. [in Russian]

Barskov, I.S., Alekseev, A.S., and Goreva, N.V., 1980, Conodonts and stratigraphic scale of Carboniferous: Izvestiya Akademii Nauk SSSR. Seriya Geologicheskaya, no. 3, p. 43-45. [In Russian]

Boardman, D.R., and Heckel, P.H., 1989, Glacial-eustatic sea-level curve for early Late Pennsylvanian sequence in north-central Texas and biostratigraphic correlation with curve for Midcontinent North America: Geology, v. 17, p. 802-805.

Boardman, D.R., and Work, D.M., 2004, Stratigraphic distribution of the ammonoids Shumardites and Vidrioceras and implications for the definition and correlation of the global Gzhelian Stage, Upper Pennsylvanian Series: Newsletter on Carboniferous Stratigraphy, v. 22, p. 23-27.

Boardman, D.R., Heckel, P.H., and Work, D.M., 2006, Conodont and ammonoid distribution across position of proposed Kasimovian-Gzhelian boundary in lower Virgilian strata in North American Midcontinent: Newsletter on Carboniferous Stratigraphy, v. 24, p. 29-34.

Boardman, D.R., Work, D.M., Mapes, R.H., and Barrick, J.E., 1994, Biostratigraphy of Middle and Late Pennsylvanian (Desmoinesian-Virgilian) ammonoids: Kansas Geological Survey, Bulletin 232, 121 p.

Bogoslovskaya, M. F., Kusina, L.F., and Leonova, T.B., 1999, Classification and distribution of Late Paleozoic ammonoids, p. 89-124, in Rozanov, A. Yu., and Shevyrev, A. A., eds., Fossil Cephalopods: Recent Advances in Their Study: Paleontological Institute, Russian Academy of Sciences, Moscow. [In Russian]

Böse, E., 1919, The Permo-Carboniferous ammonoids of the Glass Mountains, West Texas, and their stratigraphical significance: University of Texas Bulletin, 1762, $241 \mathrm{p}$.

Chernykh, V.V., 2002, Zonal conodont scale of Kasimovian and Gzhelian stages on conodonts of genus Streptognathodus, in Chuvashov, B. I., and Amon, E.O., eds., Stratigrafiya i paleogeografiya karbona Evrazii: Sbornik nauchnykh statei, Institut geologii i geokhimii Uralskogo otdeleniya RAN, Ekaterinburg, p. 302-306. [in Russian]

Chernykh, V.V., 2005, Zonal method in biostratigraphy. Zonal Conodont Scale of the Lower Permian in the Urals: Institute of Geology and Geochemistry of RAN, Ekaterinburg, 217 p. [in Russian]

Chernykh, V.V., and Reshetkova, N.P., 1987, Biostratigraphy and conodonts of Carboniferous and Permian boundary beds of western slope of southern and central Urals: Uralian Science Center, Academy of Science, USSR, p. 1-50 [in Russian]

Chernykh, V.V., Chuvashov, B.I., Davydov, V.I., and Snyder, W.S., 2006a, Potential candidate for GSSP to define base of Gzhelian Stage in global chronostratigraphic scale: Usolka section, southern Urals, Russia: Newsletter on Carboniferous Stratigraphy, v. 24, p. 23-29.

Chernykh, V. V., Chuvashov, B. I., Davydov, V. I., Schmitz, M., and Snyder, W. S., 2006b. Usolka section (southern Urals, Russia): a potential candidate for GSSP to define the base of the Gzhelian Stage in the global chronostratigraphic scale: Geologija, v. 49, p. 205-217.

Davydov, V.I., 1986, Upper Carboniferous and Asselian fusulinids of the Southern Urals, in Chuvashov, B.I., Leven, E.Ya., and Davydov, V.I., eds., Carboniferous-Permian Boundary beds of the Urals, Pre Urals and Central Asia: Nauka Publishing House, Moscow, p. 77-103. [in Russian]

Davydov, V.I., 1992, Subdivision and correlation of Upper Carboniferous and Lower Permian deposits in Donets Basin according to fusulinid data: Soviet Geology, no. 5, p. 53-61. [in Russian]

Ellison, S.P., 1941, Revision of the Pennsylvanian conodonts: Journal of Paleontology, v. 15, p. 107-143.

Goreva, N. V., and Alekseev, A. S., 2006, New conodont species from the Kasimovian Stage (Upper Carboniferous) of Moscow and Moscow Basin: Paleontological Journal, v. 40, p. 194-197.

Gunnell, F., 1933, Conodont and fish remains from the Cherokee, Kansas City, and Wabaunsee Groups of Missouri and Kansas: Journal of Paleontology, v. 7, p. 261-297.

Harris, R.W., and Hollingsworth, R.V., 1933, New Pennsylvanian conodonts from Oklahoma: American Journal of Science, v. 25, p. 193-204.

Heckel, P. H., 1994, Evaluation of evidence for glacio-eustatic control over marine Pennsylvanian cyclothems in North America and consideration of possible tectonic effects, in Dennison, J. M., and Ettensohn, F. R., eds., Tectonic and Eustatic Controls on Sedimentary Cycles: SEPM Concepts in Sedimentology and Paleontology \#4, p. 65-87.

Heckel, P.H., ed., 1999, XIV-ICCP Field Trip \#8: Middle and Upper Pennsylvanian (Upper Carboniferous) Cyclothem Succession in Midcontinent Basin. U.S.A.: Kansas Geological Survey Open-file Report 99-27, 236 p.

Heckel, P.H., 2002, Genetic stratigraphy and conodont biostratigraphy of upper Desmoinesian-Missourian (Pennsylvanian) cyclothem succession in Midcontinent North America, in Hills, L.V., Henderson, C.M., and Bamber, E.W., eds., The Carboniferous and Permian of the World: Canadian Society of Petroleum Geologists, Memoir 19, p. 99-119.

Heckel, P.H., Alekseev, A.S., Barrick, J.E., Boardman, D.R., Chernykh, V.V., Davydov, V.I., Forke, H.C., Goreva, N.V., Luppold, F.W., Mendez, C.A., Nemyrovska, T.I., Ueno, K., Villa, E., and Work, D.M., 2005, Cyclothem [sequence-stratigraphic] correlation and biostratigraphy across the Moscovian-Kasimovian and Kasimovian-Gzhelian Stage boundaries (Upper Pennsylvanian Series) in North America and Eurasia: Newsletter on Carboniferous Stratigraphy, v. 23, p. 36-44.

Heckel, P.H., Alekseev, A.S., Barrick, J.E., Boardman, D.R., Goreva, N.V., Nemyrovska, T.I., Ueno, K., Villa, E., and Work, D.M., 2007, Cyclothem ("digital") correlation and biostratigraphy across the global MoscovianKasimovian-Gzhelian stage boundary interval (Middle-Upper Pennsylvanian) in North America and eastern Europe: Geology, v. 35, p. $607-610$.

Ivanova, E.A., and Rozovskaya, S.E., 1967, To Upper Carboniferous biostratigraphy of Russian Platform in light of studies of stratotypes: Byulleten Moskovskogo Obstshestva Ispytateley Prirody, Otdel Geologicheskiy, v. 42, no. 5, p. 86-99. [in Russian]

Isakova, T.I., and Ueno, K., 2007, About lectotype of Rauserites rossicus (Schellwien, 1908) (Foraminifera) from Gzhelian of Donets and Moscow Basins: Zbirnik Naukovikh Prats Institutu Geologichnikh Nauk NAN Ukraini, Kiev, p. 105-109.

Kabanov, P., 2003, The upper Moscovian and basal Kasimovian (Pennsylvanian) of central European Russia: Facies, subaerial exposures and depositional model: Facies, v. 49, p. 243-270.

Kabanov, P., and Baranova, D., 2007, Cyclothems and stratigraphy of the Upper Moscovian-basal Kasimovian (Pennsylvanian) succession of central and northern European Russia, in Wong, Th. E., ed., Proceedings of the XVth International Congress on Carboniferous and Permian Stratigraphy: Utrecht, the Netherlands, 10-16 August 2003. Royal Netherlands Academy of Arts and Sciences, p. 147-160.

Kabanov, P.B., Alekseev, A.S., Baranova, D.B., Gorjunova, R.V., Lazarev, S.S., and Malkov, V.G., 2006, Biotic changes in a eustatic cyclothem: Domodedovo Formation (Moscovian, Carboniferous) of Peski quarries, Moscow region: Paleontological Journal, v. 40, p. 351-368.

Kozitskaya, R.I., 1978, in Kozitskaya, R.I., Kossenko, Z.A., Lipnyagov, O.M., and Nemirovskaya, T.I., Carboniferous conodonts of the Donets Basin: Izd-vo Naukova Dumka, Kiev, 136 p. [in Russian]

Kozur, H., and Mostler, H., 1976, Neue Conodonten aus dem Jungpalaeozoikum und der Trias: Geologisch - Palaeontologische Mitteilungen Innsbruck, v. 6 , no. 3,33 p. 
Merino-Tomé, O., Villa, E., Bahamonde, J. R., and Colmenero, J.R., 2006, Fusulinoidean characterization of the uppermost Moscovian-Gzhelian (upper Pennsylvanian) synorogenic depositional sequences from northern Picos de Europa Unit (Spain): Facies, v. 52, p. 521-54.

Miller, A. K., and Downs, H.R., 1950, Ammonoids of the Pennsylvanian Finis Shale of Texas: Journal of Paleontology, v. 24, p. 185-218.

Nemyrovska, T.I., and Kozitska, R.I., 1999, Species of Idiognathodus and Streptognathodus from Late Carboniferous strata of the Donets Basin, Ukraine, in Heckel, P.H., ed., 1999, XIV-ICCP Field Trip \#8: Middle and Upper Pennsylvanian (Upper Carboniferous) Cyclothem Succession in Midcontinent Basin, U.S.A.: Kansas Geological Survey Open-file Report 99-27, p. 170-173.

Nikitin, S.N., 1890, The Carboniferous of the Moscow Basin and artesian water in the region of the Moscow Basin: Transactions of Geological Committee, v. 5, (5), p.1-138 [in Russian], p.139-182 [in French].

Plummer, F. B., and Scott, G., 1937, Upper Paleozoic ammonites in Texas: University of Texas Bulletin, 3701, $516 \mathrm{p}$.

Rauzer-Chernousova, D. M., 1938, Upper Palaeozoic Foraminifera of Samara Bend and Trans-Volga region: Akademiya Nauk SSSR, Trudy Geologicheskogo Instituta, v. 7, p. 69-167. [in Russian]

Remane, J., Bassett, M. G., Cowie, J. W., Gohrbandt, K. H., Lane, H. R. Michelsen, O., and Wang, N., 1996, Revised guidelines for the establishment of global chronostratigraphic standards by the International Commission on Stratigraphy (ICS): Episodes, v. 19, p. 77-81.

Remizova, S.T., 2006, Fusulinoidea of the Kasimovian-Gzhelian transition in the northern Timan: Newsletter on Carboniferous Stratigraphy, v. 24, p. $20-22$.

Ritter, S.M., Barrick, J.E., and Skinner, M.R., 2002, Conodont sequence biostratigraphy of the Hermosa Group (Pennsylvanian) at Honaker Trail, Paradox basin, Utah: Journal of Paleontology, v. 76, p. 495-517.

Ruzhencev, V.E., 1965, Principal ammonoid assemblages of the Carboniferous: International Geology Review, v. 8, p. 48-59.

Schellwien, E., 1908, Monographie der Fusulinen. Teil I. Die Fusulinen des russisch-arctischen Meeresgebietes: Palaontographica, v. 55, p. 145-194.

Villa, E., and Task Group, 2005, Report of the Task Group to establish GSSPs at the Moscovian-Kasimovian and Kasimovian-Gzhelian boundaries: Newsletter on Carboniferous Stratigraphy, v. 23, p. 9-10.

Wang Zhi-hao, and Qi Yu-ping, 2002, Report on the Pennsylvanian conodont zonation from the Nashui section of Luodian, Guizhou, China: Newsletter on Carboniferous Stratigraphy, v. 20, p. 29-33.

Wang Zhi-hao, and Qi Yu-ping, 2003, Upper Carboniferous (Pennsylvanian) conodonts from south Guizhou of China: Rivista Italiana di Paleontologia e Stratigrafia, v. 109, p. 379-397.

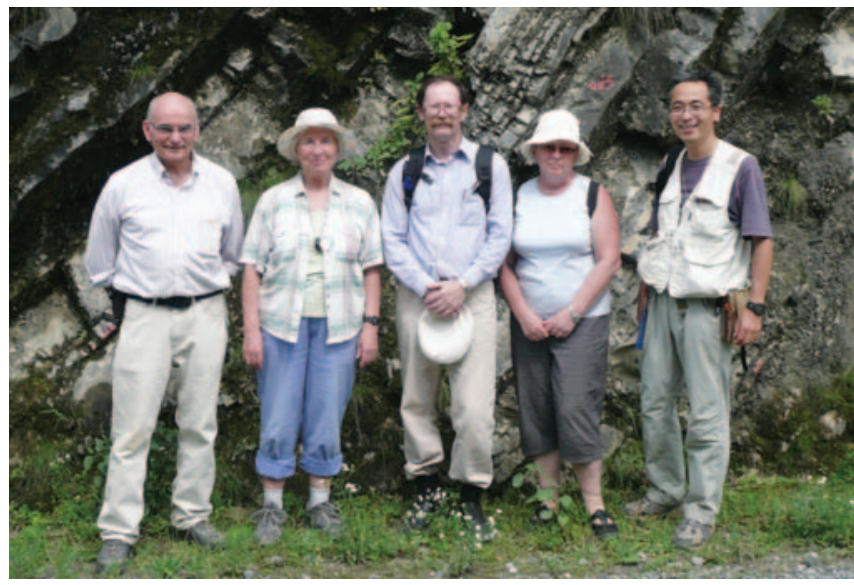

Photograph of five authors (from left, Philip Heckel, Tamara Nemyrovska, Aleksandr Alekseev, Natalya Goreva, and Katsumi Ueno) in front of the exposure of the Kasimovian-Gzhelian Stage boundary interval at the Nashui section, near Luodian, Guizhou Province, southern China, a potential candidate for the GSSP of the base of the Gzhelian Stage.

Philip Heckel is Professor of Geoscience at the University of Iowa in Iowa City, Iowa, USA. He has recently stepped down from his position as Chair of the ICS Subcommission on Carboniferous Stratigraphy from 2000-2008. His research interests are currently focused on the genetic stratigraphy and biostratigraphy of Pennsylvanian cyclothems of Midcontinent to eastern North America, and their relationships to successions of glacial-eustatic cyclothems/stratigraphic sequences elsewhere in the world. 